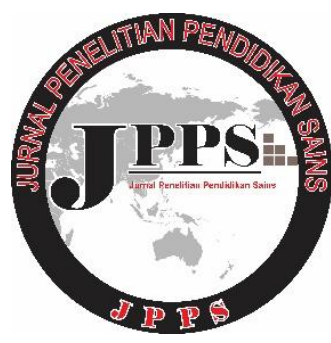

JPPS (Jurnal Penelitian Pendidikan Sains)

p-ISSN: 2089-1776

e-ISSN: 2549-1597

Volume 7, No.2, Mei 2018

https://journal.unesa.ac.id/index.php/jpps/index

\title{
THE EFFECTIVENESS OF PROBLEM-BASED LEARNING (PBL) MODELS BASED ON SOCIO-SCIENTIFIC ISSUES (SSI) TO IMPROVE THE ABILITY OF SCIENCE LITERACY ON CLIMATE CHANGE MATERIALS
}

\author{
Pungky Dilaka Putri ${ }^{1 *}$, Tukiran ${ }^{1}$, Harun Nasrudin $^{1}$ \\ 1) Postgraduate Science Education, Universitas Negeri Surabaya, Indonesia \\ *E-mail: pungkyputri16070795023@mhs.unesa.ac.id
}

\begin{abstract}
This study aimed to determine the effectiveness of Problem-Based Learning (PBL) model based on Socio-scientific Issues (SSI) to improve the ability of science literacy on climate change materials. This type of research is a 4-D model development with research design using One Group pretest-posttest design. Subjects in this study are learning devices IPA with PBS model based on SSI which is tested in this II test phase in grade VII students at SMP Negeri 1 Bangsal Mojokerto as many as 3 classes. The technique of data analysis for the result of science literacy test in learning is data of pre-test result and post-test of student that function to know improvement of science literacy of student before and after learning. This increase is known through N-Gain analysis. Based on the results of the research, it can be concluded that the learning tools of IPA with Problem Based Learning (PBL) model based on Socio-scientific Issues (SSI) to improve scientific literacy ability on climate change material developed has been effective so it is feasible to be used in learning.
\end{abstract}

Keywords: science literacy, problem based learning model, socio-scientific issues

CJurnal Penelitian Pendidikan Sains (JPPS) 


\section{INTRODUCTION}

The curriculum is a set of plans and arrangements containing the objectives, content, and lesson materials and was used in the implementation of teaching and learning process to achieve certain educational goals (Law No. 20 of 2003). The curriculum used by educational institutions now is the 2013 curriculum as a refinement of Education Unit Level Curriculum (SBC). The development of the 2013 curriculum is a refinement of mindset, governance, deepening and material expansion, strengthening teaching and learning process, and adjustment of learning load to achieve certain goals (Kemendikbud, 2013: 3). It aims to improve and balance between good abilities, having skills and knowledge to live better than some aspects of students' competencies that include attitudes, skills, and knowledge.

In the 2013 curriculum, science education is expected to enable students to learn the knowledge of themselves and the environment by applying it in their daily life. According to Subali (in Inzanah, 2014), Natural Science (IPA) is a science that comprehends various phenomena of nature systematically. Thus, science learning not only emphasizes mastery in knowledge as a product, but must provide a space for the growth of scientific attitude, practice problem solving, and apply it in everyday life. It is also concerned with science education that is geared towards preparing students for successful living in the 21 st century. Breakthroughs and advances in science/science and technology have brought great changes in improving the quality of human life throughout the world. These developments arise various issues related to ethics, morals and global issues that can threaten human life. For example, a development in the automotive field in the form of modern transportation creates new hope for human survival, but also cause new problems that threaten human life, such as air pollution caused by emissions of motor vehicles that can trigger climate change. This problem worries the global community and the problem can be solved by means of communication and cooperation among the global community. Rahayu (2014) stated that to solve the problem, it is necessary for the community to have an understanding of scientific ideas, intellectual ability, creativity, reasoning, and must have an attitude of concern for issues and problems that occur in nature. People who have these skills are said to have scientific literacy.

People with science literacy mean that the community has the knowledge and understanding of scientific concepts and processes in making decisions, being able to realize and participate actively in discussions and have a caring and able to make decisions on issues that occur in the community and the world globally. The compulsory education policy of nine years of basic education is a policy of minimum standards of human resources quality. With the policy is expected all the people of Indonesia will have science literacy (Hidayat, 2007).

Literacy of science is defined as the ability to use scientific knowledge to explain and predict natural phenomena to overcome natural problems through scientific methods (DeBoer, 2000; OECD 2014). In fact, the development of science literacy has become a top priority in the field of science education in schools (Sadler 2004; Tytler 2007). In addition, the school curriculum for science should also direct the learning of science in order to manifest students who later become a science-literate society. The new curriculum in the revised 2013 curriculum also expects this to be achieved by defining the competencies that must be possessed by students in the future such as the ability to communicate, critical thinking, consider issues in the moral side and ability to live in a global society.

This revised 2013 revised curriculum demonstrates the importance of incorporating Socio-scientific Issues (SSI) into classroom teaching and learning activities. Levinson (Gutierez, 2015) states that SSI's three-stranded framework for teachers in teaching and learning activities in the classroom, namely: 1) reasonable categories of disagreements; 2) good communication or essential characteristics to engage in reasonable disagreements; 3) narrative ideas and experiences that can explain the best disagreements.

Socio-scientific Issues (SSI) is a strategy to stimulate intellectual, moral and ethical development, and awareness of the relationship between science and social life (Zeidler, et al., 2005; Nuang-chalerm, 2010). SSI learning has moral and ethical implications. Therefore, the impetus for scientific literacy is indispensable to the moral and ethical implications of social-scientific issues. Science literacy is important for all students. Literacy of science is the ability to engage with issues related to science and scientific ideas as reflective citizens. A person who has scientific literacy, the person is willing to engage in issues related to science and technology that require competence to (a) explain scientific phenomena; (b) evaluate and design scientific inquiry; (c) interpret data and scientific evidence (OECD, 2016).

SSI learning is very important as the basis of science learning in schools. The use of SSI can serve as a problem in the life of society and the foundation by learners relating to the content of science. The application of SSI in science teaching aims to provide a more meaningful learning experience. SSI-based learning can be integrated with the problem-solving learning model. Problem-based learning or known as Problem-Based Learning (PBL) is a model of a learning approach that encourages students to develop thinking skills in formulating problems from an object in real life which is then analyzed by students (Savin-Baden, 2014). This SSI-based PBL model can be found in the global context of environmental issues in society such as climate change. In this study, the material chosen is the material of climate change. This material refers to KD 3.9 which analyzes climate change and its impacts on the ecosystem, and KD 4.9 is to write about the idea of adaptation/mitigation of climate change problems. The basic competencies contain climate change materials in accordance with the SSI-based PBL modeling model because it is local and problematic in everyday life, as well as close to the life of the students. This material is related to the relationship between the concept of science that is climate change with life in society. Therefore it is necessary to support learning devices on science learning with SSI-based PBL model in classroom learning activities.

In implementing learning in the classroom, of course, teachers have prepared the learning tools needed in teaching and learning activities. IPA learning tool is a set of materials needed by teachers to carry out teaching and learning activities in the classroom that includes the syllabus, 
lesson plan, LKS, and assessment sheet of learning result (science literacy ability assessment). All these things are prepared by teachers with reference to the curriculum applied in schools according to the rules of the government. To date, the Curriculum 2013 is a curriculum of KTSP curriculum improvement that is used in all schools in Indonesia. Therefore, learning tools are needed in accordance with the development of Curriculum 2013 in its application in schools. Development of learning tools used by teachers to determine the ability of science literacy. The ability of student science literacy can be seen by the teacher through the evaluation process.

Based on the research pre-interview with science teachers conducted by the researcher, the students of grade VII of SMP Negeri 1 Bangsal Mojokerto showed less enthusiasm to learn in following the process of learning activities in the class, lack of internal motivation from students to learn, and less ready to follow the process of learning activities in class. In the learning activities of students less active in interacting with students with teachers and students with other students. Based on the results of science literacy tests show students class VII SMP Negeri 1 Bangsal Mojokerto still have the ability of science literacy is low. This is evident from the lack of development of SSIbased learning in the increasing ability of science literacy students. Based on science literacy test of pre-research students of class VII SMP Negeri 1 Bangsal Mojokerto showed that students still have difficulty in explaining the scientific phenomenon of $44.44 \%$, evaluating and designing scientific inquiry $41.11 \%$, and interpreting data and evidence scientifically $42.22 \%$. The pre-research science literacy test showed indirectly that students' science literacy ability based on PISA 2015 in classroom learning can be said is still low so that the development of learning in the classroom in the learning process is also less than the maximum.

From the results of interviews of teachers of science teachers at SMP Negeri 1 Bangsal Mojokerto, it is found that SMP Negeri 1 Bangsal Mojokerto has implemented the 2013 curriculum. In science learning activities, most of the teachers of science teachers in SMP Negeri 1 Bangsal Mojokerto have used Problem Based Learning (PBL) but in the learning process using SSI-based PBL learning model has not been used in classroom learning activities. This is reinforced data dissemination through a pre-research questionnaire from 4 science teachers in SMP Negeri 1 Bangsal Mojokerto PBSIbased learning model based on SSI in SMP Negeri 1 Bangsal Mojokerto showing that teachers in PBL learning phase, namely: students' orientation on the issue of $25 \%$, organize students to learn by $25 \%$, guide individual and group investigation by $25 \%$, develop and present $0 \%$ work, analyze and evaluate problem-solving process by $0 \%$. While the threestranded SSI framework for teachers in the classroom learning process according to Levinson, namely: a reasonable category of differences of $25 \%$, good communication or important properties to engage in a reasonable disagreement of $25 \%$, ideas, and experiences that are narrative that can explain the best difference of opinion by $0 \%$.

The concept of learning using Problem Based Learning Model (PBL) Based on Socio-scientific Issues (SSI) is very appropriately applied to produce effective learning and can improve the ability of science literacy on climate change materials.

\section{METHOD}

The type of this research is the development of the 4-D model, which is to develop a learning tool model of Problem Based Learning (PBL) based on Socio-Scientific Issues (SSI) to improve science literacy ability on climate change material. The development of 4-D model learning tools from Thiagarajan, Semmel, and Semmel (1974), namely: define, design, development and disseminate. But the stage of dissemination is not done because the development is very wide and very long.

Subjects in this study are learning tools of IPA with PBSI model based on SSI which is tested in this II trial stage in grade VII students at SMP Negeri 1 Bangsal Mojokerto as many as 3 classes which amount to 90 students and have different academic ability (heterogenous).

The trial II in this study was piloted in 90 students. This is because 90 students can reflect the characteristics of the population. Implementation phase in the classroom using One Group pretest-posttest design (Creswell, 2015) as follows:

\section{$\mathrm{O}_{1} \mathrm{X} \mathrm{O}_{2}$}

\section{Information:}

O1: Pretest in the form of a test to determine the initial literacy ability of science students before being given treatment.

$\mathrm{X}$ : Treatment in the form of development of learning tools of SSI-based PBL model to improve science literacy ability on climate change material.

O2: Posttest in the form of a test to determine the ability of students' science literacy after treatment.

Data collection techniques used are test techniques to measure students' literacy skills in mastering the concepts given during the learning. The research instrument used in the research that is, science literacy test sheet. The technique of data analysis for the result of science literacy test in learning is data of pre-test result and post-test of student that function to know improvement of science literacy of student before and after learning. This increase is known through $\mathrm{N}$-Gain analysis.

\section{RESULT AND DISCUSSION}

Assessment tests of students' knowledge are given before (pre-test) and after (post-test) implemented the process of teaching and learning activities. The pre-test is aimed to know the students 'early ability and post-test to know the improvement of students' ability after learning based on Socio-scientific Issues Problem-Based Learning (PBL) model to improve science literacy ability on climate change material. Pre-test and post-test results are used to determine N-Gain. The N-Gain in all three classes is presented in Table 1 as follows. 
Table 1 N-Gain Value in All Three Classes

\begin{tabular}{|c|c|c|c|c|c|c|c|}
\hline \multirow[b]{2}{*}{ No. } & \multirow[b]{2}{*}{ Kelas } & \multicolumn{4}{|c|}{ Nilai } & \multirow{2}{*}{$\begin{array}{c}N- \\
\text { Gain }\end{array}$} & \multirow[b]{2}{*}{ Ket. } \\
\hline & & $\begin{array}{c}\text { Pre- } \\
\text { test }\end{array}$ & Ket & $\begin{array}{c}\text { Post- } \\
\text { test }\end{array}$ & Ket & & \\
\hline 1 & E & 48,23 & TT & 88,20 & $\mathrm{~T}$ & 0,77 & Tinggi \\
\hline 2 & $\mathrm{~F}$ & 48,17 & TT & 87,60 & $\mathrm{~T}$ & 0,76 & Tinggi \\
\hline 3 & G & 48,20 & TT & 84,23 & $\mathrm{~T}$ & 0,69 & Sedang \\
\hline
\end{tabular}

Based on Table 1. shows that the average scores of science literacy tests reached by students from the three classes at the highest pre-test were 48.23 and the lowest was 48.17 with the unfinished category. Based on the average post-test scores achieved by students on the science literacy tests obtained by the three classes at the highest post-test of 88.20 and the lowest at 84.23. The results of pre-test and posttest on students' science literacy test were measured by using

\section{KELASVIIE}

\section{Ipretest Inositest}

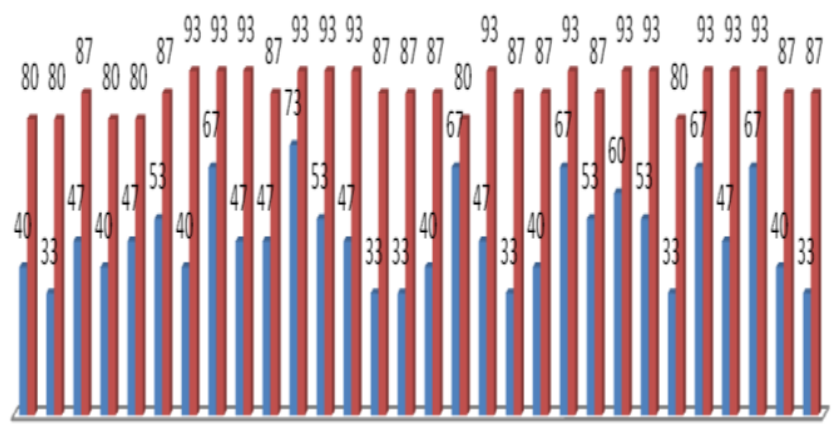

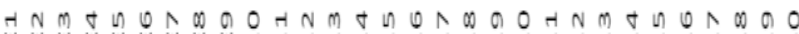

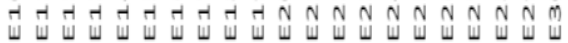

Figure 1. Score of Science Literacy Test of Class E Students

$\mathrm{N}$-Gain which showed different literacy skills of students before and after learning with Socio-scientific Issues Problem Based Learning (PBSI) model to improve literacy ability science on climate change materials. Based on Table 1. shows that the score of increase ( $\mathrm{N}-\mathrm{Gain})$ on the science literacy test is categorized high for class $\mathrm{E}$ and $\mathrm{F}$ while class $\mathrm{G}$ is categorized being. The scores of students' science literacy tests of each class are presented in the following figure.

This N-Gain enhancement, proving that learning by applying using PBL model with SSI can increase students' science literacy. Learning using the PBL model with SSI is contextual that addresses the problems that exist in everyday life. Students use their knowledge to explain existing phenomena related to climate change, analyze the causal factors and impacts of global warming, and formulate measures to reduce the effects of global warming.

Figure 2. Score of Science Literasi Test Class F Students

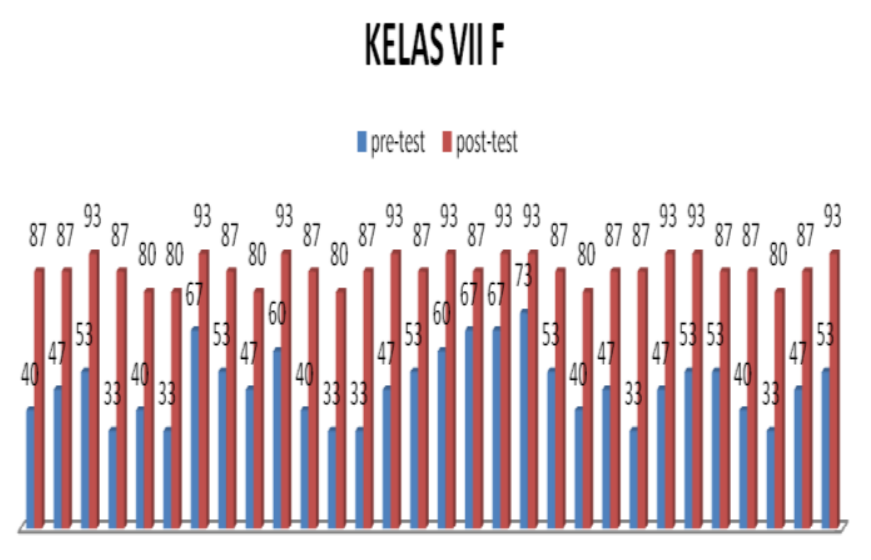

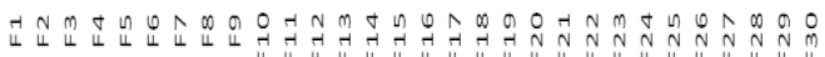

\section{KELASVIIG}

Ipretest Inost.test

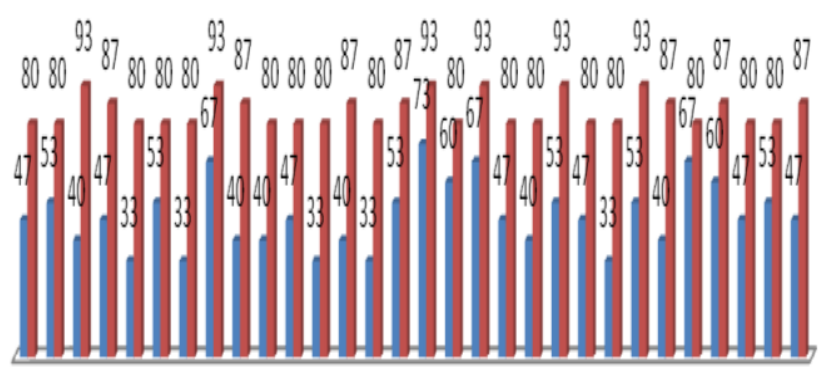

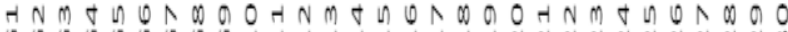

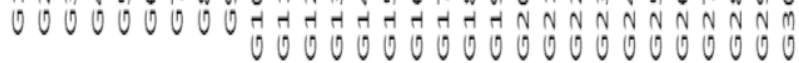

Figure 3 Score of Science Literasi Test Class G Students

The improvement indicated by the results of the analysis using N-Gain shows that the application of the development of IPA learning tools with Socio-scientific Issues Problem-Based Learning (PBL) model can improve the literacy ability of science on climate change material. In accordance with the basic framework of PISA 2015 which states that to achieve the existing competencies, students must know the context of the knowledge studied whether it is knowledge: content/content, procedural, and epestemic. The competence of science literacy 2015 will be achieved if the students have a caring attitude towards the environment. Learning by using SSI-based PBL model facilitates students to achieve the competence of PISA science literacy 2015.

Learning of SSI-based PBL model is a learning that uses authentic problems experienced by students as a starting point to gain new knowledge by relating issues or issues in social life that are conceptually closely related to science. The implementation of the SSI-based PBL model enables students to use knowledge (content/content, procedures, and epidemics) to support explanations, evaluate, and interpret data in complex life situations requiring high cognitive levels. 
Students explain inferences from complex data sources, various contexts, and explain some causal relationships.

Results of pre-test and post-test of students from all three classes if described with PISA 2015 level of Climate change materials. Achievement of science literacy ability level based on PISA 2015 from the student of class E, pre-test result that gets level 1a equal to $63,34 \%$, level 2 equal to $33,33 \%$, while level 3 equal to $3,33 \%$. Post-test results that get level 4 of $56.67 \%$, while level 5 of $43.33 \%$. The pre-test and post-test results with the PISA 2015 grade F grade assessment, the pre-test results obtained level 1a of $56.67 \%$, level 2 by $40 \%$, while level 3 of $3.33 \%$. Post-test results that get level 4 of $66.67 \%$, while level 5 of $33.33 \%$. The pre-test and post-test with PISA 2015 grade $\mathrm{G}$ grade assessment, pretest result that got level 1a $63,34 \%$, level 2 equal to $33,33 \%$, while level 3 equal to 3,33\%. Post-test results obtained level 4 of $80 \%$, while level 5 by $20 \%$.

Level of students' science literacy ability according to PISA 2015 which get the highest percentage at level 1a $63,34 \%$ from $\mathrm{E}$ and $\mathrm{G}$ students, level 2 is $40 \%$ from grade $\mathrm{F}$ students, level 4 is $80 \%$ from $\mathrm{G}$ grade students, and level 5 amounted to $43.33 \%$ of students class E. While the achievement level of students' science literacy ability according to PISA 2015 who get the lowest percentage at level 1a of $56.67 \%$ of students of grade F, level 2 of $33.33 \%$ of students class E and G, level 4 of $56.67 \%$ of students of grade E, and level 5 of $20 \%$ of students of class $\mathrm{G}$. The low achievement of this level is because during this learning is only memorizing only. The results of this study are supported by the previous studies results (Prahani, et al., 2015; Prahani, et al., 2018; Yasir, et al., 2016) that the media, teaching materials, devices, and learning models of quality and feasible (meet the valid, practical, and effective aspects) can improve student learning outcomes. This is supported by the acquisition of PISA 2015 results. Students have not gained level 6 because the students that researchers use as the first research object to apply learning with SSI-based PBL model.

\section{CLOSURE}

\section{Conclusion}

Based on the results of the analysis, discussion, and discussion, it can be concluded that the learning tools of science with Problem-Based Learning (PBL) model based on Socio-scientific Issues (SSI) to improve the ability of science literacy on climate change material developed has been effective so it is feasible to be used in learning.

\section{Acknowledgments}

My gratitude for the preparation of this scientific article, first of all, I say gratitude and thanks to Allah SWT who has provided ease and fluency in working on this article. The second I say thank you very much to my supervisor lecturer Prof. Dr. Tukiran, M.Si and Dr. Harun Nasrudin, M.S and also not my parents, as well as the parties from SMPN 1 Bangsal Mojokerto school who have launched my research data as well as my dear friends in motivating me relentlessly. Thank you all.

\section{REFERENCES}

DeBoer, G.E. (2000). Scientific literacy: Another look at its historical and contemporary meanings and its relationship to science education reform. Journal of Research in Science Teaching, 37(6), 582-601.

Gutierez, S.B. (2015). Integrating socio-scientific issues to enhance the bioethical decision-making skills of high shool students. International Education Studies, 8(1),1913-9020.

Inzanah. (2014). Pengembangan Perangkat Pembelajaran IPA Berbasis Kurikulum 2013 Untuk Melatihkan Literasi Sains Siswa SMP. Jurnal Penelitian Pendidikan Sains, 4(1).

Nuangchalerm, Prasart, and Kwuanthong, B. (2010). Teaching "global warming" through socioscientific issues-based instruction. Journal of Asian Social Science, 6 (8), 42-47.

OECD. (2014). PISA 2012 Results in Focus. Programme for International Student Assessment, 1-44.

OECD. (2016). PISA 2015 assesment and analytical framework: science, reading, mathematic and financial literacy. http://doi.org/10.1787/9789264255425-en

Prahani, B.K., Soegimin, W.W., and Yuanita, L. (2015). Pengembangan perangkat pembelajaran fisika model inkuiri terbimbing untuk melatihkan keterampilan penyelesaian masalah berbasis multi representasi siswa SMA. Jurnal Penelitian Pendidikan Sains, 4(2), 503517.

Prahani, B.K., Suprapto, N., Suliyanah, Lestari, N.A., Jauhariyah, M.N.R, Admoko, S., and Wahyuni, S. (2018). The effectiveness of collaborative problem based physics learning (CPBPL) model to improve student's self-confidence on physics learning. Journal Physics: Conference Series, 997(1), 012008.

Rahayu, S. (2014). Menuju masyarakat berliterasi sains: Harapan dan tantangan kurikulum 2013. Makalah disajikan dalam Seminar Nasional Kimia dan Pembelajarannya (SNKP) 2014, Jurusan Kimia FMIPA Universitas Negeri Malang.

Ratumanan, T.G. (2015). Belajar dan pembelajaran, serta faktor-faktor yang mempengaruhinya. Yogyakarta: Unesa University Press.

Savin-Baden. (2014). Using problem-based learning: New constellations for the $21^{\text {st }}$ century. Journal on Excelllence in College Teaching, 25(3), 197-219.

Thiagarajan, S., Semmel, D., S and Semmel, M., I. 1974. Instructional Development for Training Teachers of Expectional Children. Minneapolis, Minnesota: Leadership Training Institute/Special Education, University of Minnesota.

Yasir, M., Ibrahim, M., and Widodo, W. (2016). Pengembangan perangkat pembelajaran biologi berbasis metakognitif untuk melatihkan kejujuran siswa. Jurnal Penelitian Pendidikan Sains, 5(2), 1109-1015. 
Zeidler, D.L. (2005). Beyond STS: A Research-Based Framework for Socioscientific Issues Education. Journal of Science Education, 89(3), 357-377. 